attacks '(Mill Fever).' Thanks to John Pemberton's (and others') research at The Queen's University of Belfast, Flax Byssinosis became a Prescribed Industrial Disease in 1965.

\section{C SHIPBUILDING IN BELFAST IN THE EARLY TWENTIETH CENTURY: THE TITANIC ERA AND ASSOCIATED HEALTH AND SAFETY MATTERS}

K Addley. Faculty of Occupational Medicine, Royal College of Physicians of Ireland, Dublin, Ireland

\subsection{6/oemed-2018-ICOHabstracts.533}

In the 1830's, factory-based linen production had made Belfast the most important industrial town in Ireland and the addition of shipbuilding in the 1880 's completed its transformation to a major manufacturing city. There was access to a ready pool of unskilled local labour with a robust work ethic and shipbuilding was one of the city's main employers giving it both wealth and prestige. It was a vibrant, expanding industry whose later decline greatly affected Belfast and its people. The period between 1880 - 1914 was the golden age of Belfast shipbuilding, with massive growth in the industry specialising in passenger liners, cargo-passenger ships and large ocean-going cargo vessels. During this time, Belfast was producing up to $10 \%$ of the British merchant shipping output. Harland and Wolff is the best known of the Belfast shipbuilders employing in the period 1900-20, 20000 workers. Between 1914 - 1918 saw the beginning of a decline of shipbuilding in Belfast. Shipyard work was heavy and hazardous with many physical hazards including falls, noise and vibration. Asbestos was frequently used leading to asbestosis, pleural plaques, and pleural mesothelioma. There were safety and health shortcomings consistent with the time and a health legacy in regard to asbestos-related lung disease, mesothelioma, occupational deafness and vibration white finger. There was recognition of the potential that materials being used may have long latency health risk, avoiding complacency, also that learning from mistakes and improved engineering design and safety equipment on board vessels can markedly improve worker safety and health and save lives. The workers of the Belfast shipyard would perhaps be proud to see their story being told today as part of the regeneration of Belfast with the city moving forward after many years of conflict and decline.

\section{8d OCCUPATIONAL HEALTH IN IRELAND AS A PROFESSION - THE LAST 50 YEARS. WHILE RAMAZINNI IS THE GRANDFATHER OF OCCUPATIONAL HEALTH, IS THERE AN IRISH PHYSICIAN WHO IS THE GREAT GRANDFATHER OF OCCUPATIONAL HEALTH?}

JM Malone. The Faculty of Occupational Medicine Royal College of Physicians of Ireland

\subsection{6/oemed-2018-ICOHabstracts.534}

The Faculty of Occupational Medicine, Royal College of Physicians of Ireland (RCPI) was founded in 1976. Its objective was to advance the science and practice of occupational medicine and to promote education, study and research in the specialty. Its core membership has all-Ireland representation, stemming from the College's Royal Charters in the seventeenth century. The Faculty has been an integral part of RCPI since its inception. The Faculty was involved in occupational medicine being recognised as both an Irish and
European Medical Specialty. It developed the Licentiate and Membership Examinations which became sought after qualifications at home and abroad. It has held annual examinations in Ireland since 1983 and holds annual overseas examinations in Malaysia since 1995 and more recently in the $\mathrm{Al}$ Ain. The Faculty initiated and maintains a comprehensive training scheme for its specialist doctors in training. This paper gives a chronological account of the activities of the Faculty, from the mid1970's up to current times. It is based on the archive records of the Faculty, including the minutes of the Board meetings of the Faculty and the College (RCPI). It covers that period of change that affected many disciplines involved in occupational health i.e. nurses, hygienists, toxicologists, safety officers, psychologists and others, as well as the changes that the factory doctor underwent as he/ she became a 21 st century occupational physician. The role of the Faculty is to maintain integrity and professional competence of doctors engaged in occupational medicine. It operates the professional competence scheme on behalf of the Medical Council for specialist occupational health physicians.

\section{OCCUPATIONAL HEALTH AND SAFETY PERSPECTIVES OF LOUISIANA FIRST RESPONDERS INVOLVED IN THE 2010 DEEPWATER HORIZON OIL SPILL}

${ }^{1} J o h n a t h a n$ Z Pangborn*, ${ }^{1}$ Kevin J Moore, ${ }^{1}$ Katerina M Santiago, ${ }^{2}$ Edward J Trapido, ${ }^{3}$ Wilma A Subra, ${ }^{4}$ Lora E Fleming, ${ }^{1}$ Alberto I Caban-Martinez. ${ }^{1}$ University of Miami, Miller School of Medicine, Department of Public Health Sciences, Miami FL, USA; ${ }^{2}$ Louisiana State University, School of Public Health, Department of Epidemiology, New Orleans LA, USA; ${ }^{3}$ Subra Company, Louisiana Environmental Action Network, Lower Mississippi Riverkeeper, New Iberia LA, USA; ${ }^{4}$ European Centre for Environment and Human Health, University of Exeter Medical School, Truro, Cornwall, UK

\subsection{6/oemed-2018-ICOHabstracts.535}

Introduction The 2010 Deepwater Horizon oil spill is considered the largest accidental marine oil spill in United States history. The oil spill had severe environmental impacts on the United States Gulf coastline as well as far-reaching effects on the health and safety of first responders. Despite national significance of the oil spill, there is limited information documenting the long-term health and safety experience of this workforce. This study examines the occupational health and safety perspectives of first responders involved in the 2010 Deepwater Horizon oil spill.

Methods Six focus group sessions (8-10 participants each) were conducted in May 2017. Firefighters were consented and invited to complete a self-administered questionnaire, followed by a $60 \mathrm{~min}$ semi-structured focus group session assessing perceptions of safety and health conditions related to the oil spill event. Focus group audio files were transcribed verbatim and analysed using a general inductive approach to identify emergent themes.

Result Study participants $(\mathrm{n}=50)$ were mostly male $(98.0 \%)$, non-Hispanic $(95.3 \%)$, white $(98.0 \%)$, with a mean age of 40.6 years (standard deviation $[\mathrm{SD}]=9.8$ ), and mean job tenure of 15.3 years $(\mathrm{SD}=8.2)$. Among respondents, $56.3 \%$ of participants reported direct contact with oil, $36.7 \%$ visited a doctor after the oil spill, and $18.8 \%$ reported feeling chronic ( $\geq 3$ months) musculoskeletal pain following recovery efforts. Major themes that emerged included concerns regarding personnel decontamination procedures, heat-related illnesses, ocular disorders, fear of cross-contamination, and unknown long- 